\title{
Factors Affecting the Health Condition of Spruce Forests in Central European Mountains-Study Based on Multitemporal RapidEye Satellite Images
}

\author{
Radomir Bałazy ${ }^{1, *}$, Tomasz Hycza ${ }^{1}$, Agnieszka Kamińska ${ }^{1}$ (D) and Katarzyna Osińska-Skotak ${ }^{2}$ (D) \\ 1 Forest Research Institute, SękocinStary, ul. Braci Leśnej 3, 05-090 Raszyn, Poland; \\ t.hycza@ibles.waw.pl (T.H.); a.kaminska@ibles.waw.pl (A.K.) \\ 2 Warsaw University of Technology, PlacPolitechniki 1, 00-661 Warsaw, Poland; \\ Katarzyna.Osinska-Skotak@pw.edu.pl \\ * Correspondence: r.balazy@ibles.waw.plor radomir.balazy@gmail.com; Tel.: +48-22-7150-343
}

Received: 19 September 2019; Accepted: 22 October 2019; Published: 24 October 2019

\begin{abstract}
Spruce stands in the mountains of Central Europe are particularly valuable, not only because of their natural and scenic values but also because of their role in the protection of watersheds and soil. Over the past decades, these stands were frequently exposed to massive deforestation caused by various biotic, abiotic and anthropogenic factors. The current health condition of spruce stands in the Eastern Sudetes shows that the next phase of deterioration of these stands has begun. Bearing in mind past experiences and the current situation in these mountain areas, it is particularly important to understand the processes and factors that may short-term (2012-2016) spruce health analyses based on the normalized difference red-edge index and RapidEye satellite imagery, which is being delivered annually. Aided by remote sensing data and Boosted Regression Trees, it was possible to determine the topographic and tree stand features having the greatest impact on the vitality of spruce in all analyzed areas during 2012-2016. As the results show, the highest impact on the value of the normalized difference red-edge index indicator comes from a height above sea level, age of stands, terrain slopes, and exposure. In various areas, these factors may affect the vitality of spruce to varying degrees but not always in the same way. Our models accurately explained $74-81 \%$ of the randomly selected input data (predicted $72-80 \%$ of the excluded data) for site A, $50-58 \%$ for site B ( $48-57 \%$ for tested data) and $54-70 \%$ for site C (52-69\% for excluded data).
\end{abstract}

Keywords: spruce; vitality; vegetation index; topography; remote sensing

\section{Introduction}

The mountainous areas of Central Europe are a special place, not only because of their natural and scenic values but also because of their water and soil-protecting role. Presently, due to topography and weather conditions prevailing in these mountains, these areas are particularly vulnerable to deforestation and forest dieback. This process has occurred in Central Europe since the late 1970s (especially in the Western Sudetes), when air pollution reached its highest levels and resulted in the decline of forest stands. Mass dieback of forests started in Poland in the years 1977-1982 coinciding with an outbreak of the larch bud moth-Zeirapheragriseana, mainly in the most polluted areas of the Sudety Mountains [1,2]. Consequently, over 15,000 hectares of forests were completely deforested (approximately $26.9 \%$ of our study area in Western Sudetes). Although forest dieback progression in the Western Sudety Mountains seemed to be under control and air pollution had decreased [3] since the end of 20th century, the mortality of spruce increased significantly in the western Beskidy [4-6] where the land surface affected by deforestation processes reached $7 \%$. At present, forest dieback is becoming 
aproblem in the Eastern Sudetes, where dying spruce may be observed on a mass scale. Based on a theory expressed by Manion [7] and called "spiral disease", we believe that a combination of air pollution, root pathogens, drought periods, improper species composition or provenance, and insect pests are generally responsible for the observed forest decline $[3,8]$. Spruce mortality in eastern Europe is caused by several factors, including pollution [9,10], secondary pest outbreaks [11-15], climate change and atmospheric disturbances [16,17]. In most studies, individual factors are analyzed. Only a few of them focused on the interactions between multiple factors $[3,18,19]$.

The mortality of spruce stands and the reduction of their annual growth in European forests are related to the accumulation of air pollutants, which depends on topography [20-22]. The process was analyzed using airborne laser scanning (ALS) data, which resolution had improved from hundreds of meters to several centimeters in the last two decades $[23,24]$. There is still a large portion of uncertainty regarding how this forest dieback process occurred, which one of the topographic factors contributed most and what was the significance of their impacts. We also need some further research on annual tree vitality variation for different mountain ranges.

Precise topographic data, together with repeated satellite observations, have been employed to perform further and more accurate health condition analysis at a single tree or stand level. In previous studies of vegetation health, multispectral Landsat satellite imagery [25-29], WorldView data [28,30], RapidEye data [31-33] and SPOT data [29] have been studied. These images can provide the basis for the creation of many different vegetation indexes, among which the Normalized Difference Vegetation Index (NDVI) is best known $[25,27,29-31,34]$. The addition of a red-edge channel to a RapidEye display enables even more advanced health condition analyses. Eitel [31] concluded that the normalized difference red-edge index (NDRE) allowed to detect stress 13 days after girdling (ring barking) which was 16 days earlier than possible when using broad band spectral indexes, such as the NDVI (normalized difference vegetation index) and the GNDVI (green NDVI) traditionally used for satellite-based forest health monitoring. Adelabu [33] found that the use of the red-edge band increases the insect defoliation detection accuracy by 19-21\% in southern Africa [32]. Combining the NDRE and the NDVI in one discriminant function and achieved the increase of overall accuracy of $7.4 \%$ whilst detecting defoliation of a Scots pine plantation affected by a nun moth outbreak.

\section{The Aim of the Study}

The aim of the study is to explore the influence of age and topographic factors (elevation, aspect, slope) on the vitality of spruce stands in different mountains ranges, thanks to repeated satellite images acquired between 2012 and 2016.

\section{Material and Methods}

\subsection{Study Area}

Three different mountain ranges in Central Europe were chosen for analysis: Western Sudety (Area A), Eastern Sudety (Area B) and Beskid Ślaski and Beskid Żywiecki (Area C) (Figure 1). 


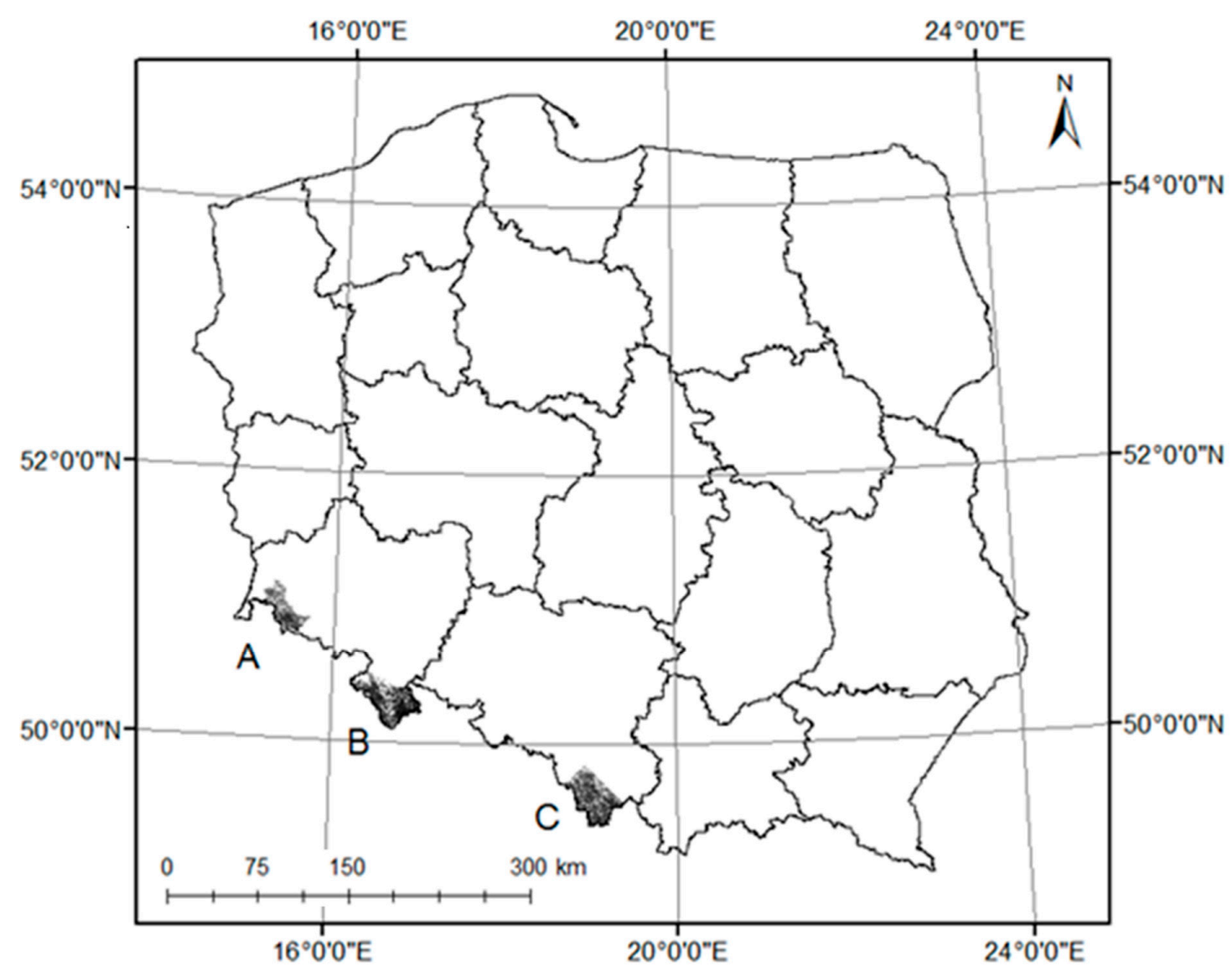

Figure 1. The areas of investigation.

We emphasize that all three areas analyzed are in different stages of growth and that they also differ in terms of stand structure. Western Sudety (Area A) is an area that was affected by deforestation most strongly in the 1980s. This was mainly due to air pollution (causing acid rains) and primal species composition change, especially in the lower mountainous areas (deciduous species were replaced by spruce from a foreign provenance). Eastern Sudety (Area B) is an area where the existing stands were also considerably rebuilt, and the harvested areas were regenerated almost solely with spruce. This area did not suffer as much as Western Sudety did, but recent droughts, combined with insect pests, caused forest dieback on mass scales. Beskid Ślaski and Beskid Żywiecki (Area C) are areas where foreign spruce provenances were also introduced; however, unlike in Western Sudety, air pollution did not play a significant role inforest health. Among all areas analyzed, this is the one having suffered the most in years 2012-2016, due to forest dieback on a mass scale caused by a bark beetle outbreak [19,35].

The spatial resolution of the RapidEye images is $6.5 \mathrm{~m}$, and the radiometric resolution is 12 bits ( 5 meters and 16 bits after the resampling). The images consist of five spectral bands: Blue (440-510 nm); green (520-590 nm); red (630-685 nm); red-edge (690-730 nm); and near-infrared $(760-850 \mathrm{~nm})$. The images were already put under atmospheric, radiometric and geometric correction in the ENVI 5.5. software, so there was no need for further pre-processing except masking out clouds (manually).

Study area A (Figure 2) consists of 2 forest districts in the southwestern part of Dolnoślaskie Voivodeship: Świeradów-Zdrój and Szklarska Poręba $\left(292.4 \mathrm{~km}^{2}\right)$. The most common tree species are spruce $(74.3 \%)$, birch $(10 \%)$, pine $(7.2 \%)$, oak $(4.6 \%)$, beech $(3.7 \%)$ and larch $(3.1 \%)$ (Table 1$)$. A total of $6.6 \%$ of the forest area belongs to the I age class, 51\%-II, 39.8\%-III, 31\%-IV, 25 - $\%$-V and 36.8\%-VI (Table 2) [36]. The images of area A, B and C were obtained on the 2nd August 2012, 21st July 2013, 4th July 2014, 7th July 2015 and 23rd May 2016. The images were chosen due to a little amount of cloud and fog. 

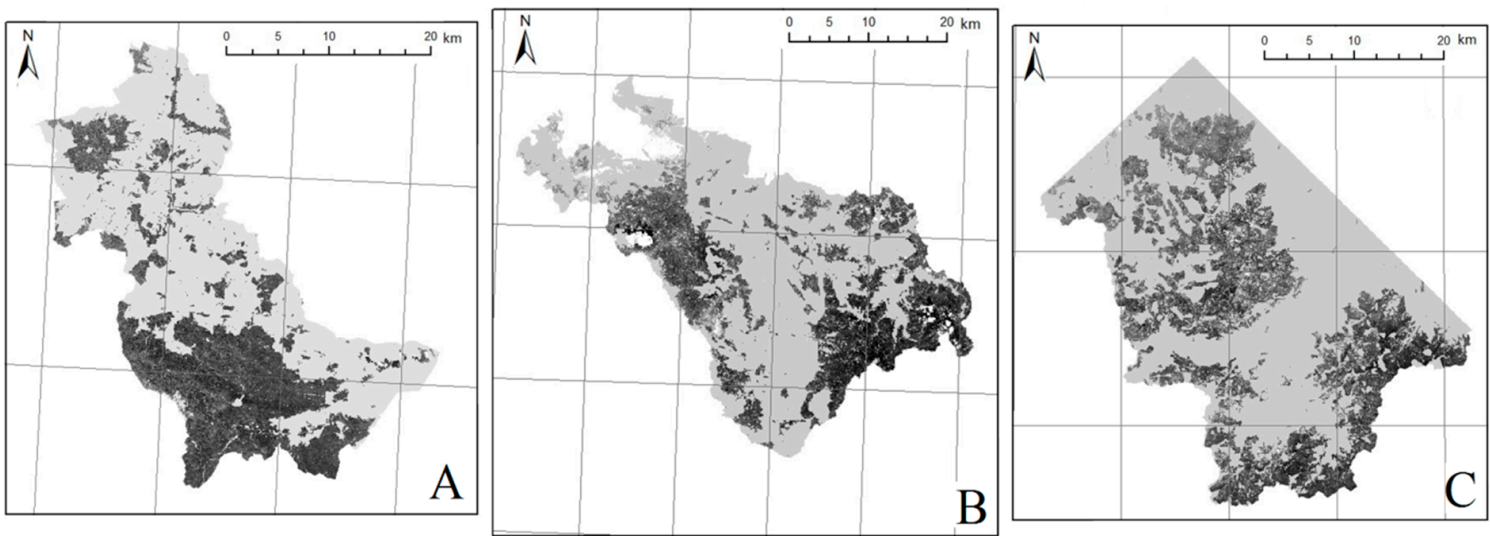

Figure 2. Study area A (Western Sudety), B (Eastern Sudety) and C (Western Beskidy)-State Forests.

Table 1. Forest structure in three areas: A-Western Sudety, B-Eastern Sudety and C-Western Beskidy [Forest Data Bank, 2019].

\begin{tabular}{cccc}
\hline Species & Area A & Area B & Area C \\
\hline Spruce & $74.3 \%$ & $82.2 \%$ & $56.9 \%$ \\
\hline Larch & $3.1 \%$ & $1.9 \%$ & $2.1 \%$ \\
\hline Birch & $7.2 \%$ & $1.1 \%$ & no data \\
\hline Pine & $4.6 \%$ & $2.4 \%$ & $2.3 \%$ \\
\hline Beech & $3.7 \%$ & $9.2 \%$ & 29.1 \\
\hline Fir & no data & no data & $3.5 \%$ \\
\hline Oak & $4.4 \%$ & no data & no data \\
\hline Other & $7.0 \%$ & $3.2 \%$ & $6.1 \%$ \\
\hline
\end{tabular}

Table 2. Species composition in three areas: A-Western Sudety, B-Eastern Sudety and C-Western Beskidy [Forest Data Bank, 2019].

\begin{tabular}{ccccccc}
\hline & Area A & Area A & Area B & Area B & Area C & Area C \\
\hline Age & Spruce & Other & Spruce & Other & Spruce & Other \\
\hline $0-20$ years & $1.6 \%$ & $5.0 \%$ & $1.5 \%$ & $10.1 \%$ & $19.7 \%$ & $19.5 \%$ \\
\hline $20-40$ years & $33.5 \%$ & $27.5 \%$ & $11.7 \%$ & $21.0 \%$ & $19.2 \%$ & $14.7 \%$ \\
\hline $40-60$ years & $19.1 \%$ & $20.7 \%$ & $17.5 \%$ & $14.8 \%$ & $13.2 \%$ & $15.0 \%$ \\
\hline $60-80$ years & $13.2 \%$ & $17.8 \%$ & $13.6 \%$ & $13.7 \%$ & $16.5 \%$ & $15.5 \%$ \\
\hline $80-100$ years & $14.6 \%$ & $10.4 \%$ & $18.9 \%$ & $10.1 \%$ & $7.2 \%$ & $14.9 \%$ \\
\hline$>100$ years & $18.1 \%$ & $18.7 \%$ & $36.8 \%$ & $30.3 \%$ & $24.3 \%$ & $20.3 \%$ \\
\hline
\end{tabular}

Study area B (Figure 2) consists of 4 forest districts in the southern part of Dolnośląskie Voivodeship: Zdroje, Bystrzyca Kłodzka, Lądek Zdrój and Międzylesie $\left(495.5 \mathrm{~km}^{2}\right)$. The most common tree species are spruce $(82.2 \%)$, beech $(9.2 \%)$, pine $(2.4 \%)$, larch $(1.9 \%)$ and birch $(1.1 \%)$ (Table 1$)$. A total of $11.6 \%$ of the forest area belongs to the Iage class, 32.7\%-II, 32.3\%-III, 27.1\%-IV, 29\%-V and 67.1\%-VI (Table 2) [36]. The images of area B were obtained on the 23rd and 27th July 2013, 20th July 2014, 11th July 2015 and 27th August 2015.

Study area C (Figure 2) consists of 6 forest districts in the southern part of Ślaskie Voivodeship: Węgierska Górka, Wisła, Ujsoły and partly Ustroń, Jeleśnia and Bielsko (489.5 km2). The most common tree species are spruce $(56.9 \%)$, beech $(29.1 \%)$, pine $(3.5 \%)$, fir $(2.3 \%)$ and larch $(2.1 \%)$ (Table 1$)$. A total 
of $39.2 \%$ of the forest area belongs to the I age class, $34.1 \%-\mathrm{II}, 28.2 \%-\mathrm{III}, 32 \%-\mathrm{IV}, 22.1 \%$-V and $44.6 \%$-VI (Table 2) [36]. Images of area C were obtained on the 24th July 2013, 11th July 2015 and 22nd May 2016.

In 2012, all three areas were scanned using an Airborne Laser Scanning system, which produced three DEMs (Digital Elevation Models) and three DSMs (Digital Surface Models). The data were saved as LAS files. The average density of points was $6 / \mathrm{m} 2$, and the accuracy was between 0.15 ( $\mathrm{Z}$ factor) and $0.2 \mathrm{~m}$ (X, Y factor). The image was registered as PUWG (National Geodetic Coordinates System) 1992 and 2000 (ALS Full Waveform). The DEM and the DSM were used to produce maps of elevation and aspect. The spatial resolution (size of a pixel) was $5 \mathrm{~m}$ for elevation and slope and $100 \mathrm{~m}$ for aspect (to reduce the influence of local topographic variability).

The Digital Forest Map provided information about the areas covered by the National Forests (excluding private ones) and the average age of the stands. The Forest Digital Map was obtained from the Regional Directories of National Forests in Wrocław and Katowice.

Data were collected, and analysese were performedas part of the science project entitled "The creation of the forest informational system for the monitoring and the forest state estimation on the area of Sudety and West Beskidy" financed by the Polish National Forest Holding.

The goal of the project is to describe reasons, progression, and results of the ecological disaster in Sudety and West Beskidy and to create a model to forecast future disasters, as well as the forest monitoring system.

\subsection{Response Variable and Predictors}

Vegetation indexes are used to analyze the health conditions of the plants, the amount of chlorophyll, and water and nutrient levels in the foliage. They are a mathematical combination of spectral bands defined as the band of light wavelengths for which the light is reflected. The RapidEye satellite images contain fivespectral bands, which may be used as variables in the mathematical formulas. Some indexes requiring very narrow spectral bands are dedicated tothe hyperspectral data. The most widely recognized indexes may be calculated using wide spectral intervals. One of the most popular vegetation indexes is the Normalized Difference Vegetation Index (NDVI):

$$
\mathrm{NDVI}=(\mathrm{NIR}-\mathrm{R}) /(\mathrm{NIR}+\mathrm{R})
$$

where NDVI is normalized difference vegetation index; NIR is near-infrared; and R is red.

There are many indexes designed to analyze the health condition of plants in specified atmospheric and ecological conditions, e.g., SAVI (Soil Adjusted Vegetation Index) used to reduce the influence of the soil on the reflectance, ARVI (Atmospherically Resistant Vegetation Index) used to reduce the influence of the atmosphere on reflectance, GNDVI (Green Normalized Difference Vegetation Index) designed to analyze vegetation of high density and many others.

As the red-edge spectrum is sensitive to changes in plant condition, it can be useful to detect woodland stress. Usually, it is available only from hyperspectral data, but there are some broad band sensors with a red-edge band, such as RapidEye. Studies comparing the use of imagery with the red-edge band with broadband imagery not providing such a band proved that use of the red-edge band couldbe more useful for detecting changes in vegetation conditions. Decreasing reflectance in that band is usually associated with lower-vitality trees. Indexes using red-edge, e.g., NDRE-normalized difference red-edge index, are known to better detect stress or any decline in forest health than NDVI [31-33].

$$
\mathrm{NDRE}=(\mathrm{NIR}-\mathrm{RE}) /(\mathrm{NIR}+\mathrm{RE})
$$

where NDRE is normalized difference red-edge index.; andRE is red-edge.

To analyze the subtle changes among the values of the index, an identical dataset of pixels must be analyzed each year. It is also very important to choose images that were taken in similar periods of the growing season. Finally, 5 images were compared for Area A (2nd August 2012, 21st July 2013, 4th July 2014, 7th July 2015 and 23rd May 2016), 4 images for Area B (23rd-27th July 2013, 20th July 
2014, 11th July 2015 and 27th August 2016) and 3 images for Area C (24th July 2013, 11th July 2015 and 22nd May 2016). If one of the chosen images contained areas covered by fog or clouds, these areas were clipped from all of the images. The areas of logging activities, roads and non-forested sections were also clipped from each image. Each analyzed dataset from one of the areas contained the same number of pixels.

A mean value of NDRE vegetation index, age, elevation, slope and aspect were calculated for each $25 \times 25$ m plot. The number of plots was 223,698 (13,981.125 ha) for study site " $A$ ", 480,072 (30,004.5 ha) for study site " $\mathrm{B}$ " and 516,782 for study site " $\mathrm{C}$ " (32,298.875 ha). The plots contained most of the forest area on all three study sites, excluding features listed in the previous paragraph. The distributions of pixels among the classes are listed in Tables 3-5. The results were analyzed by the boosted regression trees technique, which has been used by other authors to analyze the vitality and mortality of spruce stands in mountain forests [37].

The distribution of area among classes is shown in Figures 3-5.

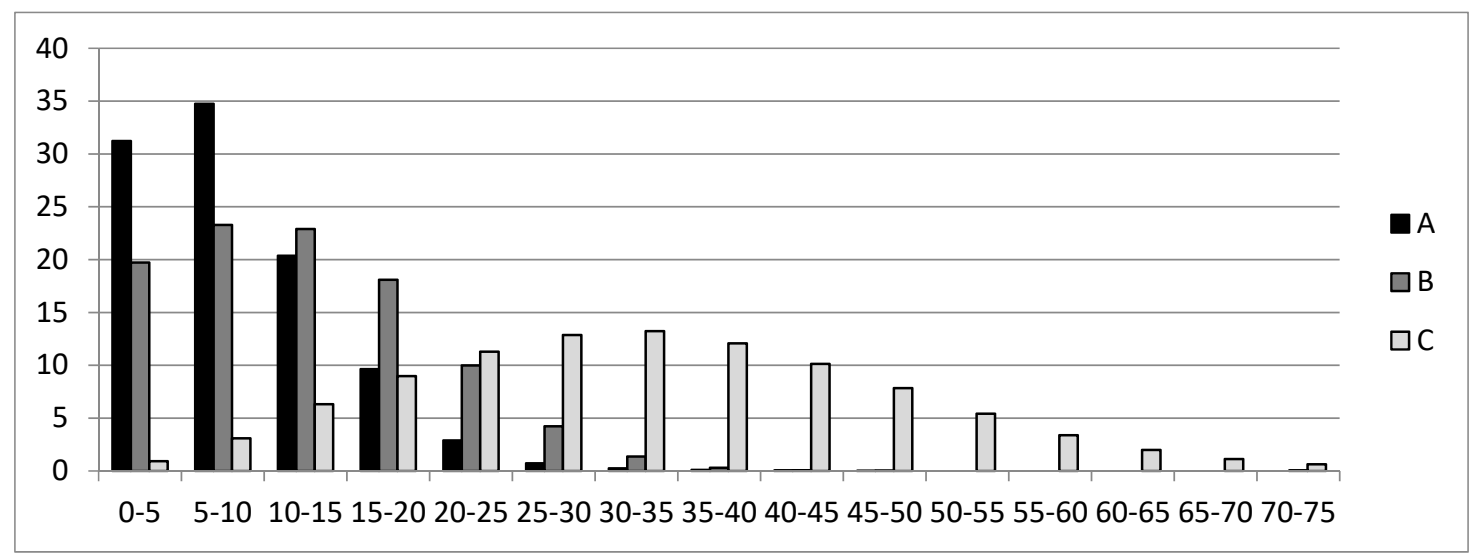

Figure 3. Area distribution for slope classes (\% of area vs. slope classes in degrees).

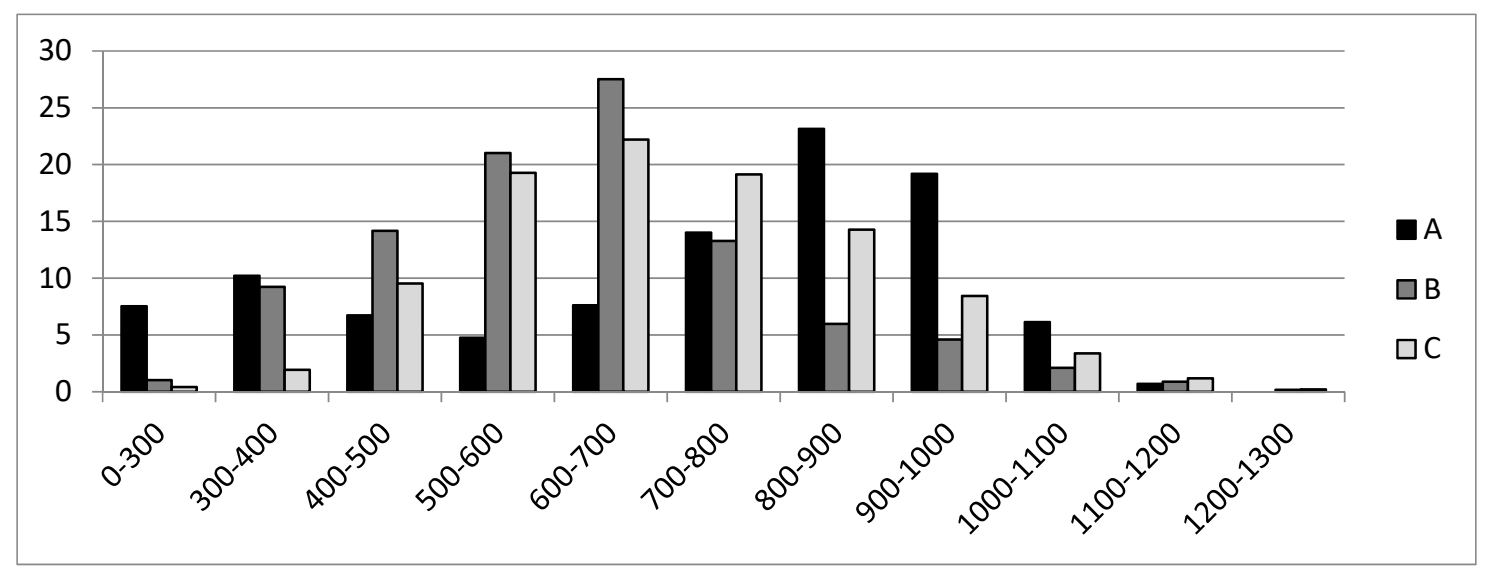

Figure 4. Area distribution for elevation classes (\% of area vs. elevation classes in meters). 


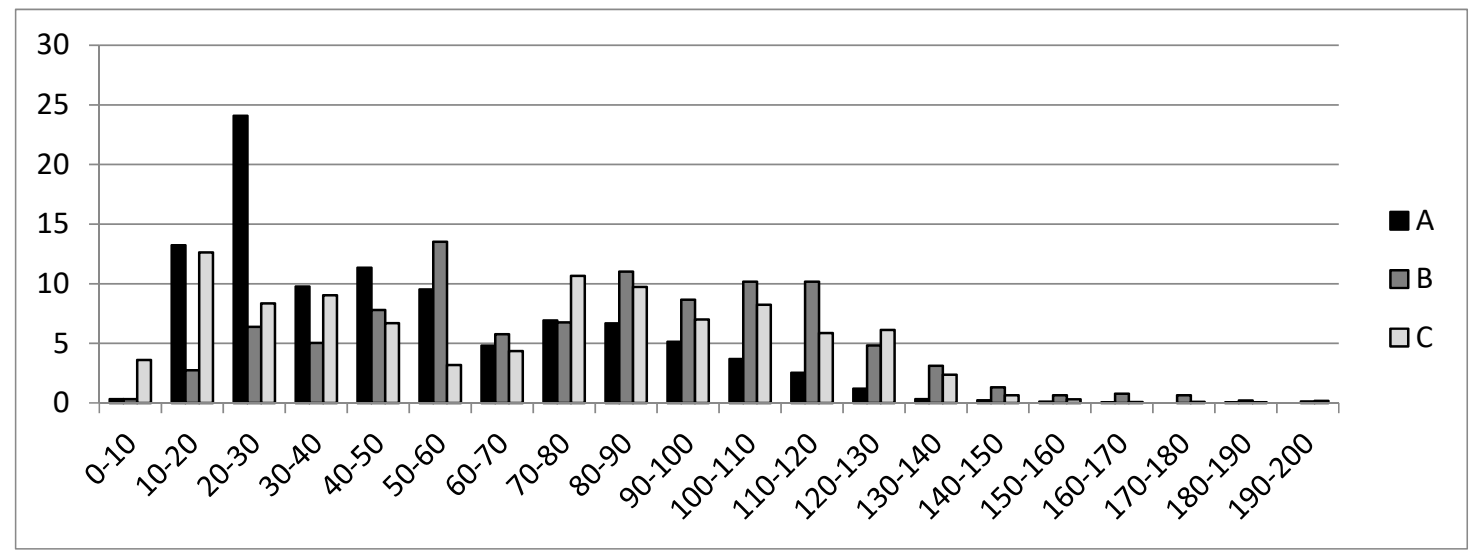

Figure 5. Area distribution forage classes (\% of area vs. age classes in years).

\subsection{Boosted Regression Trees}

Boosted regression trees [38], are a robust machine-learning alternative to traditional regression analyses and were used to find the most important factors influencing znormalized difference red-edge index and study the nature of theserelationships for each year (2012-2016) and for each site (A, B and C). The advantage of BRTs is that there is no need to drop prior to predictors. They can fit complex nonlinear relationships; they automatically account for interaction effects between predictors; and they can handle different types of response data [38]. The general idea of BRT statistical technique is to compute a sequence of simple trees, where each successive tree is built for the prediction residuals of the preceding tree. BRT models are provided on the basis of how good each model explains the observed data (training data correlation) and how well excluded data can be predicted (CV (cross-validation) correlation). Relative importance values are generated for all predictors (totalling up to $100 \%$ for all included variables) to indicate each variable's relative contribution to the model [35,36]. It is based on how often the variable is selected and its ability to improve the model. The fitted function visualization in a BTR model is reached using partial dependence functions that demonstrate the effect of a variable on the response after accounting for the average effect of all other variables in the model [38].

In our analysis, models were fitted in R version 3.0.3 (R Development Core Team 2015) with the gbm package [39] and an extension developed by Eitel et al. [31] and ElithandLeathwick [40], with a Gaussian response distribution and 10-fold cross-validation procedures, as explained by Elith et al. [38]. Each model was fitted with a tree complexity (number of nodes) of three, a bag fraction (proportion of data selected at each step) of 0.75 , and a learning rate of 0.0005 .

The study areas were partitioned into a $25 \times 25 \mathrm{~m}$ square fishnet patterns. The means of NDRE vegetation index, elevation, slope and aspect were calculated for each $25 \times 25 \mathrm{~m}^{2}$ plot and served as input for the Boosted Regression Trees analysis. If the plot contained pixels outside the study area or wasclipped due to clouds, fog, forest management, or lack of trees (Norway Spruce in particular), the values of these pixels were ignored in the calculations.

\section{Results}

Based on the collected data, a descriptive analysis was done for the values of NDRE vegetation index and predictors. It is worth noting that, for all study areas (A, B and C), the ranges of mean and median values of NDRE are very similar (almost identical). Moreover, they were characterized by low diversity (Table 3). Moreover, they were characterized by low diversity (Table 3). 
Table 3. Ranges of summarized statistics of normalized difference red-edge (NDRE) vegetation index. $\mathrm{SD}$ is the standard deviation and $\mathrm{CV}$ is the coefficient of variation.

\begin{tabular}{ccccc}
\hline Area & Mean & Median & SD & CV \\
\hline A & $0.47-0.62$ & $0.47-0.62$ & $0.04-0.08$ & $0.09-0.13$ \\
\hline B & $0.48-0.56$ & $0.47-0.56$ & $0.05-0.07$ & $0.10-0.12$ \\
\hline C & $0.45-0.50$ & $0.45-0.50$ & $\approx 0.05$ & $\approx 0.10$ \\
\hline
\end{tabular}

Figure 3, Figure 4 andFigure 5 show box and whisker plots of the response variable and predictors (elevation, age and slope) for each study area (A, B and C). Comparing study areas, site C was characterized by lower values of response variable. In Sudety (areas A and B), the highest average values of NDRE were recorded in 2016 compared to previous years, while in Beskidy, the means did not differ significantly between the analyzed periods.

The study areas varied depending on the predictor values (Table 4). The lowest ranges and the highest values of $\mathrm{CV}$ of elevation, age, and slope were seen for site $\mathrm{A}$, relative to the other study areas. For site $\mathrm{A}$, the mean and median values for age and slope were significantly lower than the average values recorded for $B$ and $C$, whereas for site $C$, the values were the highest.

Table 4. Summarized statistics of predictors elevation, age and slope for sites A, B and C. SD means standard deviation and CV coefficient of variation.

\begin{tabular}{ccccccc}
\hline Predictor & Area & Mean \pm SD & Median & Min & Max & CV \\
\hline Elevation & A & $704.63 \pm 247.45$ & 781.47 & 208.18 & 1126.8 & 35.117 \\
\hline Elevation & B & $717.52 \pm 176.21$ & 712.44 & 304.81 & 1402.3 & 24.559 \\
\hline Elevation & C & $797.70 \pm 172.40$ & 784.75 & 312.95 & 1365.2 & 21.613 \\
\hline Age & A & $53.03 \pm 31.13$ & 44.20 & 10.05 & 185.0 & 58.715 \\
\hline Age & B & $80.95 \pm 34.19$ & 83.00 & 10.09 & 223.0 & 42.240 \\
\hline Age & C & $70.79 \pm 39.01$ & 75.00 & 10.08 & 253.0 & 55.111 \\
\hline Slope & A & $8.46 \pm 5.52$ & 7.35 & 0.11 & 48.8 & 65.256 \\
\hline Slope & B & $12.41 \pm 7.53$ & 11.63 & 0.08 & 90.0 & 60.655 \\
\hline Slope & C & $33.10 \pm 13.84$ & 32.36 & 0.33 & 90.0 & 41.808 \\
\hline
\end{tabular}

The results of BRT modeling of the NDRE index, using four predictor variables, are presented in Tab. 5. Models accurately explained $74-81 \%$ of the randomly selected input data (and predicted $72-80 \%$ of the excluded data) for site A and slightly less of the data for the others: $50-58 \%$ for site B ( $48-57 \%$ for tested data) and $54-70 \%$ for site C (52-69\% for excluded data). 
Table 5. Boosted regression tree predictor importance values, related to NDRE.

\begin{tabular}{ccccccccc}
\hline Area & Year & Elevation & Slope & Age & Aspect & $\begin{array}{c}\text { Training Data } \\
\text { Correlation }\end{array}$ & $\begin{array}{c}\text { CV } \\
\text { Correlation }\end{array}$ & $\begin{array}{c}\text { Standard } \\
\text { Error }\end{array}$ \\
\hline A & 2012 & 69.6 & 8.8 & 18.6 & 3 & 0.74 & 0.72 & 0.002 \\
\hline A & 2013 & 74.1 & 11 & 12.9 & 2 & 0.76 & 0.74 & 0.001 \\
\hline A & 2014 & 80.4 & 8 & 9.5 & 2.1 & 0.81 & 0.8 & 0.001 \\
\hline A & 2015 & 72.1 & 12.7 & 12.3 & 2.9 & 0.75 & 0.73 & 0.001 \\
\hline A & 2016 & 75.2 & 8.8 & 11.7 & 4.3 & 0.77 & 0.76 & 0.001 \\
\hline A & Avg & 77.8 & 10.9 & 9.6 & 1.7 & 0.81 & 0.80 & 0.001 \\
\hline B & 2013 & 43 & 26.5 & 23.5 & 7 & 0.54 & 0.52 & 0.001 \\
\hline B & 2014 & 35.4 & 38.2 & 20.6 & 5.9 & 0.58 & 0.57 & 0.001 \\
\hline B & 2015 & 24.2 & 36.6 & 30.3 & 8.9 & 0.5 & 0.48 & 0.001 \\
\hline B & 2016 & 43.9 & 20.6 & 25.7 & 9.9 & 0.56 & 0.54 & 0.001 \\
\hline B & Avg & 38.7 & 27 & 29.2 & 5.2 & 0.57 & 0.56 & 0.001 \\
\hline C & 2013 & 31.7 & 8.6 & 54 & 5.7 & 0.56 & 0.54 & 0.001 \\
\hline C & 2015 & 35.5 & 12.7 & 45.9 & 5.9 & 0.54 & 0.52 & 0.001 \\
\hline C & 2016 & 66.9 & 5.3 & 24.9 & 2.9 & 0.7 & 0.69 & 0.001 \\
\hline C & Avg & 45.7 & 42.1 & 8.1 & 4.1 & 0.62 & 0.60 & 0.001 \\
\hline
\end{tabular}

The importance of analyzed predictors differed between sites. Elevation was the best predictor of NDRE with the highest relative importance percentage for all years at site A (0.70-0.80), slopes and ages had similar importance $(0.8-0.20)$. Aspect was not a significant predictor, showing a relative contribution of less than 0.05 for each analyzed year. For site B, among all four predictors, there is no dominant predictor, and little contribution to the BRT models by aspect was observed $(<0.10)$. For site C, elevation $(0.32-0.67)$ or age $(0.25-0.54)$ is the better predictors than the other two factors (the relative importance for both (aspect and slope) was less than 0.13 for each of the years).

Comparing each period for each site, the BRT models work most poorly for area B. It is worth noting that elevation was the best predictor of NDRE in 2016 for every site; the second most important was age, followed by a slope. The smallest contribution to the 2016 models came from the aspect. In general, aspect was not a key contributor for predicting the vegetation index. For all years, when the range of species age showed a greater range, the relative importance of age as a predictor for NDRE became greater. This means that the greatest age contribution to the BRT models for site $C$ was observed in contrast to site A. In the case of site B, slope exhibited higher relative importance relative to the other areas.

Visualization of fitted functions in the BRT model is easily accomplished using partial dependence functions that show the effect of a variable on the response after accounting for the average effects of all other variables in the model (Figure 6, Figure 7, and Figure 8). They show that there is a linear decrease in NDRE with increasing values of elevation and little contribution to the models is present for aspect. 

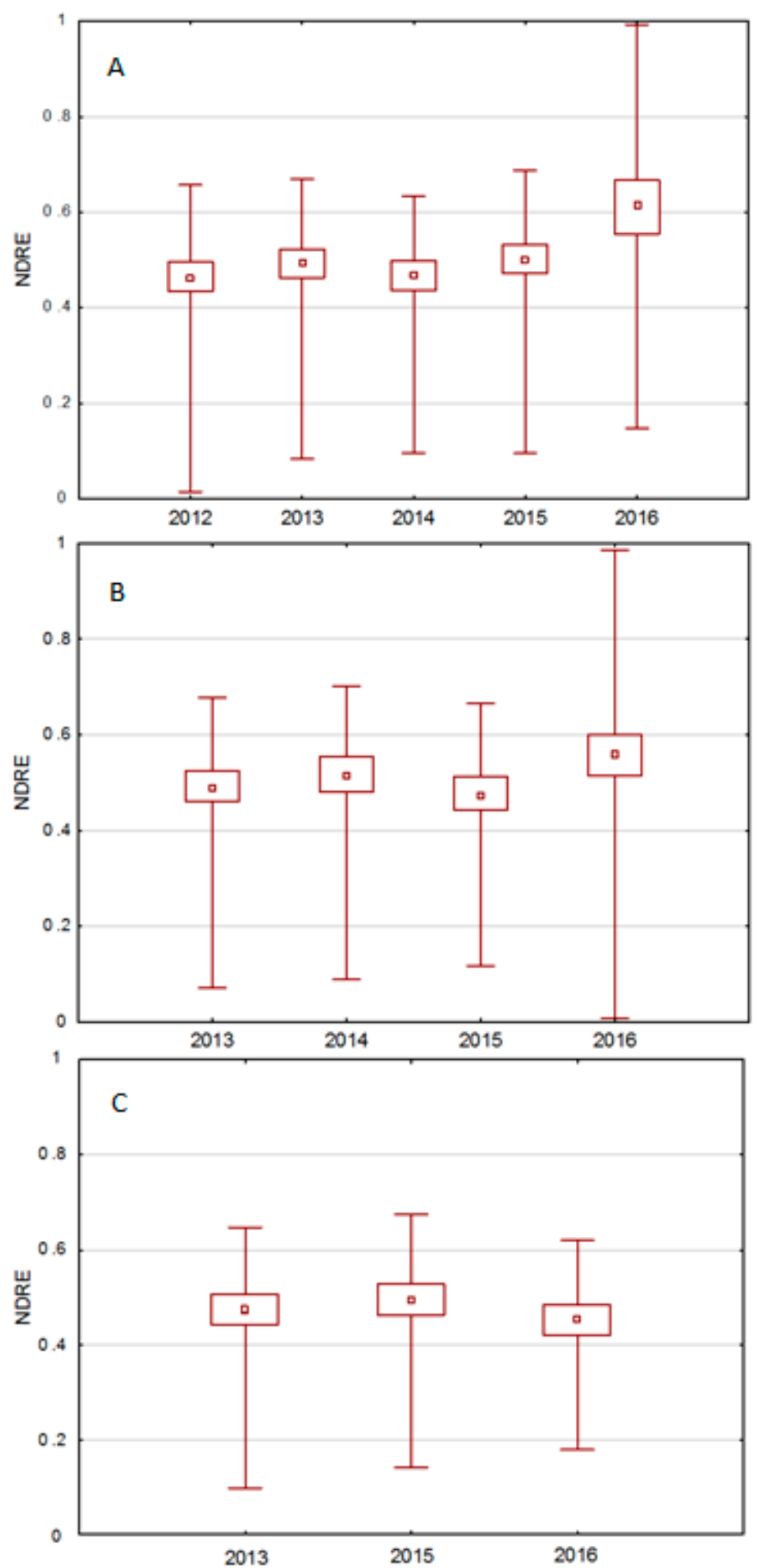

Figure 6. Box and whisker plot of the NDRE vegetation index for area A, B and C. The first and third quartiles define the box; the median is shown as " $\square$ "; and the whisker defines the range of the data. 

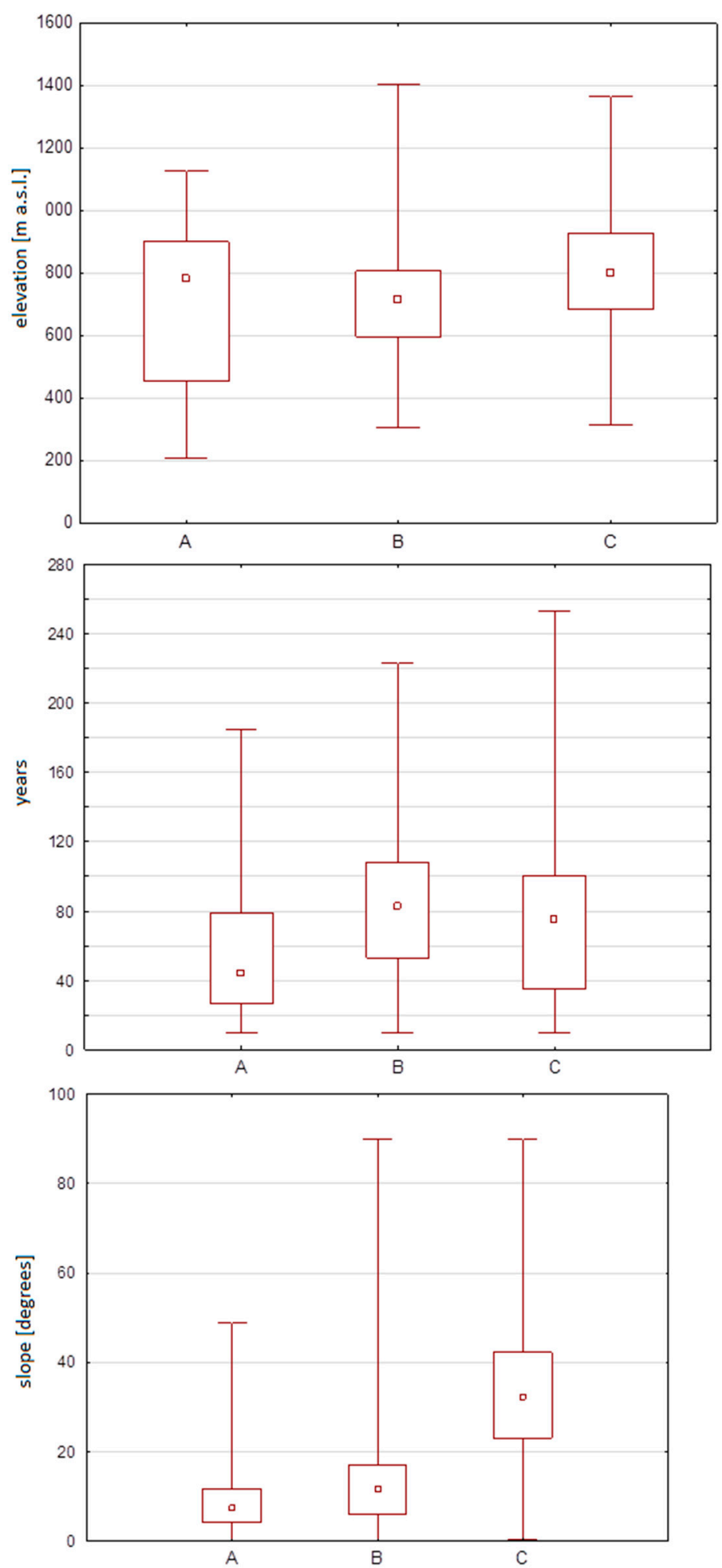

Figure 7. Box and whisker plot of elevation, age and slope for area A, B and C. The first and third quartiles define the box; the median is shown as " $\square$ " and the whisker defines the range of the data. 
A
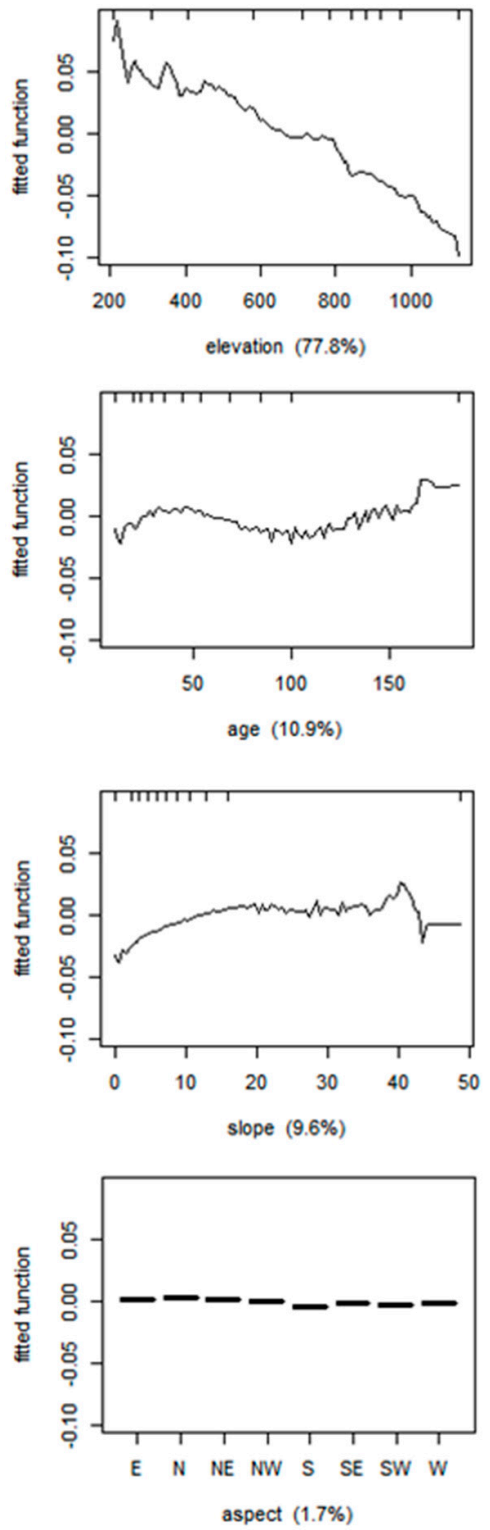

B
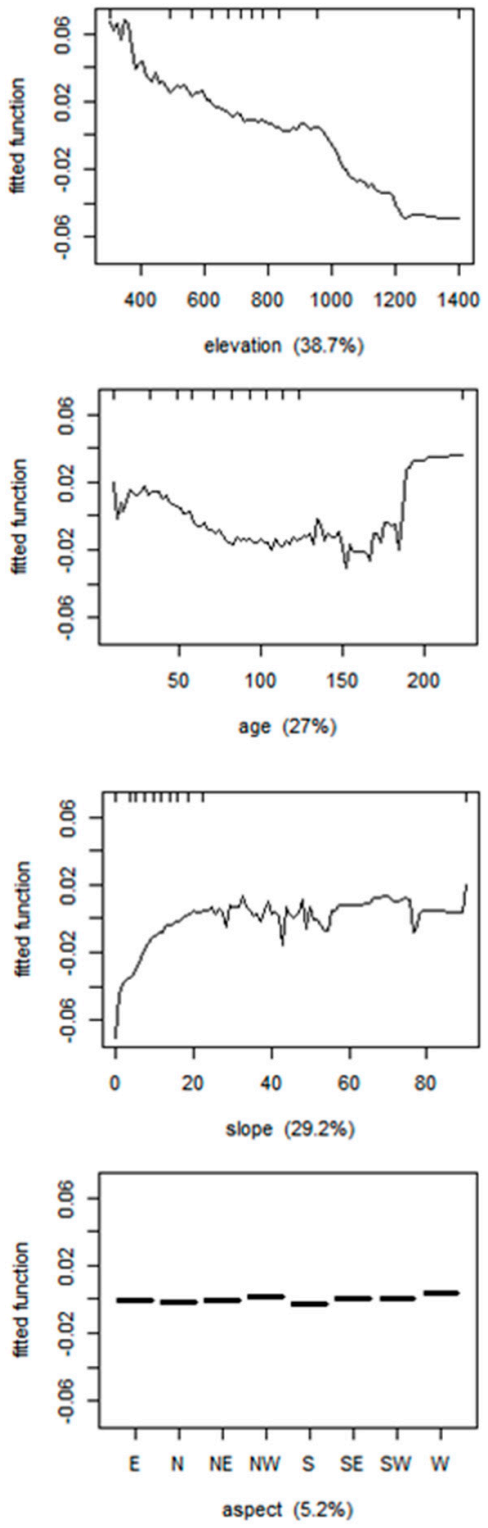

$\mathrm{C}$
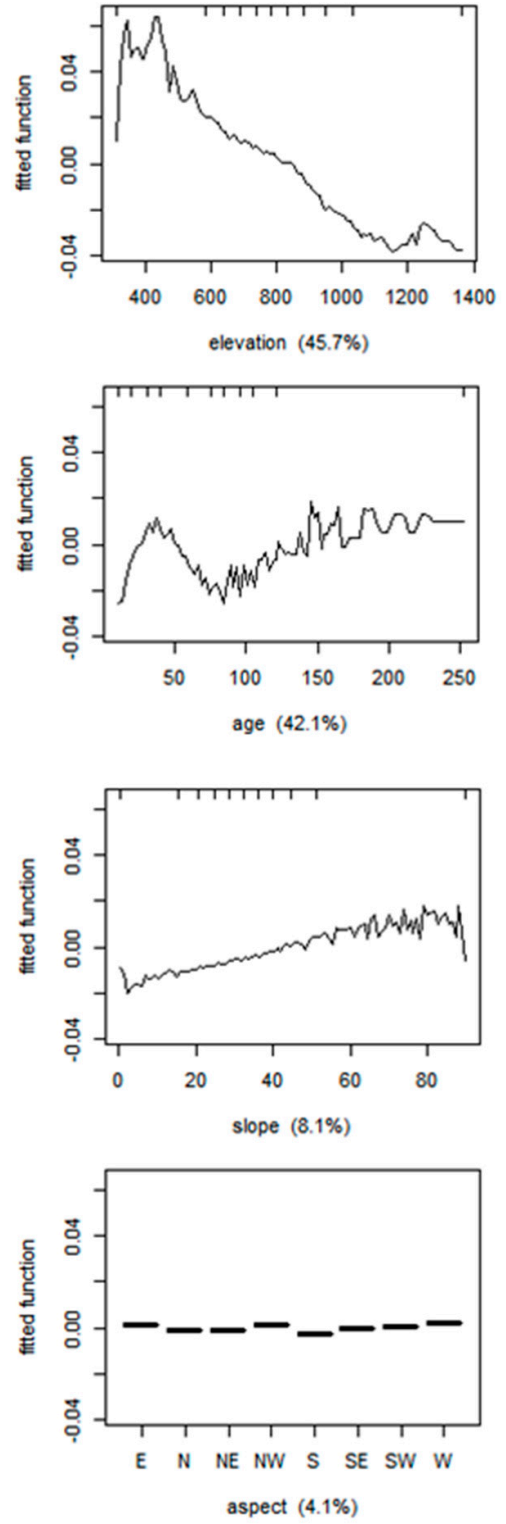

Figure 8. Partial regression plots between predictors and average values of NDRE for area A, B and C.

For BRT models with a key contribution from elevation (sites A and C-2016), no distinct trends for the remaining three factors were observed. Additionally, for site B, the dynamic increase in NDRE exhibited increasing values of slope up to approximately 20 degrees, above which no distinct trends were observed. For site $C$, slope showed a positive association with response. Interesting trends for age were observed. For site $C$, the dynamic increase in NDRE with increasing values of age took place up to approximately 50 years, at which point the relationship leveled out; after approximately 100 years, positive trends were again observed. For site B, at ages between 50 and 100 years, the fitted function showed significantly lower values.

\section{Discussion}

During the course of our research, various BRT models were constructed, bringing us closer to a description of the relationship between the selected topographic attributes, age, and Norway Spruce health conditions in the Sudety and the Carpathian Mountains. 
For all three areas, the elevation is the topographic element most strongly affecting spruce health for those samples analyzed. The greater the elevation, the lower the NDRE value. NDRE, for the case of elevation, may be influenced by wax morphology and the reflectance of spruce, which is increasing because chlorophyll content and photochemical efficiency decrease with elevation [41]. However, it is not the case that the NDRE values always decrease as the elevation increases. There are cases in the literature demonstrating that the values of vegetation indexes reach their optimum for certain height ranges. There is also the phenomenon of pollutant accumulation in the valleys, which adversely affects spruce health in these areas [42-44]. The decrease in the vitality of spruce stands as elevation increases werealso observed by other authors [45-48], who indicate elevation as one of the reasons for weaker spruce conditions and greater susceptibility to insect pests $[49,50]$. Elevation explains most of the variability of the NDRE indicator in the Western Sudetes, which may be related to location, (these stands constitute the first orographic barrier in the path of moving air masses arriving from the west and from the southwest) and which has the harshest climate of all three analyzed areas.

Interestingly, in all three areas, stabilization of the NDRE indicator for the range of 800-1000 m is seen for the case of elevation. For the Western Sudetes, the characteristic flattening of the NDRE value occurs at lower elevations (800-900 $\mathrm{m}$ above sea level) than in the Eastern Sudetes (over 900-1000 m above sea level), which may be related to less favorable climatic conditions for spruce growth, with more favorable conditions prevailing in the Western Sudetes. Godek et al. [51] prove that between 600-900 m a.s.l., there is a decrease in the negative influence of atmospheric factors on spruce health. They suggest that, above this elevation zone, there is a deterioration of the forest's health status caused by wind and rime (which accumulates a great amount of toxic deposition), especially on the ridges and mountain peaks. The results of their study confirm our observations only partially, as we observed the improvement or stabilization in the NDRE index both in the Eastern Sudetes and for the highest elevations of the Beskid Ślaski and Żywiecki Mountains. This may be related to tree density and thinning of the crowns which may differ on different elevations [52] and influencing of reflections from the low vegetation, but it may also reflect slightly better health at approximately 1,300 $\mathrm{m}$ a.s.l, which is noted in a study by Faccoli and Bernardinelli [48].

The second element influencing the value of the NDRE indicator is age, which is observed most strongly the Western Sudetes and the Beskid Ślaski and Beskid Żywiecki. Interestingly, these are the two areas that, in recent times, were affected by the mass dieback of spruce, occurring earlier (1980s) in the Western Sudetes. A much greater influence of age on NDRE is observed in the Silesian and Żywiecki Beskids, and a greater proportion of stands in younger age classes exists, being a natural consequence of recent deforestation. Such an age-class structure, besides what was stated by Faccoli and Berardinelli [48] may also have an influence on vitality and in consequence on NDRI value. Younger trees may have a different reflectance comparing to old stands. It was also proven that bark beetles prefer older spruce stands over younger ones [5]. The steep drop and increase of the NDRE vegetation index on area " $C$ " may be caused by the bark beetle itself, which prefers spruce stands of a specific age. The trend was observed by Modzelewska [53] on the same study sites using four different vegetation indexes (NDVI, NDRE, gNDVI and WDRVI). The drop of the vegetation indexes was observed for tree height and volume, which are directly correlated with age for particular species in similar natural conditions. It is also possible that a more complex species composition affects the results on area " $\mathrm{C}$ ", because of a higher abundance of other species, including broad-leaves. Moreover, it is also possible, that a $5 \mathrm{~m}$ resolution is not enough to get rid of this effect, which leads to higher values of the NDRE in particular pixels.

Interestingly, at two areas, in Western Sudetes and in Eastern Sudetes variation values for NDRE observed in 2016 are significantly higher comparing other years. It is possible that relatively high temperatures on summer 2015 and relatively high precipitation in on spring 2016 (compared to other periods) led to a greater difference between the health condition of spruce stands. However, it does not explain why the relative variability of the values is higher in 2016. Different results for 2016 may also be a consequence of acquiring satellite image in a May not in July or August like in 2012-2015. 
It should be underline additionallythat statistical tests which we have conducted separately for each year confirmed that the amount of data from one satellite image per year is enough to get statistically significant results. The influence of age and topography on the health condition of spruce stands doesnot depend on the annual changes of temperature or humidity. They may cause higher or lower values of the vegetation index but doesnot affect the original trend, that the higher/lower the altitude (the steeper/flatter the slope, the older/younger the stand), the better/worse condition of a forest stand.

For the case of the Eastern Sudetes, the slope has a greater influence on the NDRE index slope than does the age of stands, the shape of the curve of the age indicator is similar to the shape of the same parameter in the Western Sudetes. In both areas, the age structure of spruce stands in the age range 0-100 years is similar (there is a lower proportion of 0-20 years and 40-60 years classes in relation to the class of 20-40 years). Interestingly, the impact of the slope, as the most important factor after elevation, was only seen in the area of the Eastern Sudetes. Findings by Sproull et al. [45], and similar to Mezei et al. [37], proved that slope couldbe important in the process of deterioration of spruce stands and it affects the probability of spruce dieback. However, this work shows that, for the case of the Western Sudetes and the Silesian Beskids with the Beskid Żywiecki, this is a small impact. For all three areas, the slope is positively correlated with an increase in NDRE. Additionally, the accuracy of the numerical terrain model used, which may be slightly lower for the case of slope [54], was not significant in the areas analyzed because it was based on models having relatively low resolution, corresponding to the pixel size of RapidEye images. Interestingly, analysis of dead trees performed for these areas and based on much more accurate data (ALS and aerial photos), but obtained only in 2012, showed [19] that slope is positively correlated with the tree mortality exclusively in the Western Sudety. The slope had no impact for the Eastern Sudety and Beskidy. An analysis based solely on data from one year could, however, be compromised by a greater degree of randomness of tree damage, and thus, may differ from the analyses performed on the basis of longer-term data.

In all three areas, southern exposure is the one for which spruce trees show the poorest health. This observation is also confirmed by other authors who analyzed the presence of dead trees and bark damage [46,49,55]. The latest dendrochronological, climate [17,51], and remote sensing research [24], confirms the relationship between topography, winds, and spruce vitality. The research also confirmed higher spruce vitality for the EN-NE exposure for the case of the Western Sudetes, NW-W in the case of Eastern Sudetes and E-NW-W exposures for the case of the Silesian Beskid and Beskid Żywiecki. The noticeable similarity between the Eastern Sudetes and the Silesian Beskids and Beskid Żywiecki may be related to the trend of the mountain ranges which, for the case of these two areas, have an axis closer to the trend of the meridians.

It should be underlined that the presented study focused on topographical factors and age, which are only a small part of a whole palette of different elements influencing forest vitality, for example, tree density [52]. There is no doubt that one of such a factor may be soil and humidity together with forest site types. It seems, however, based on the other studies for these areas $[19,56]$ that more important for forest condition is where the stands are located in the mountain range than what type of forest soils they are growing on. For this particular area, it was also proven by Opała-Owczarek [57] based on dendrochronological sampling method. Humidity, indirectly represented by TWI index, were also analyzed within this study and results confirmed a very weak correlation with NDRE index. On the one hand, these results contradict those obtained by other authors [58], on the other hand, it should be remembered that TWI helps to indicate wet areas, but it is not used to determine changes in water resources. Groundwater data were not taken into account within this study.

Our results, developed from many years of observation, allow us to define regions with lower spruce vitality in all three mountain areas. These results can contribute directly to the development of detailed spruce health maps and can be used by foresters to determine locations that should be monitored more frequently due to the potentially poorer health of spruce. It may be crucial especially now, when climate changes speeding up, influencing in the same time on species ranges. 


\section{Conclusions}

Elevation was the best predictor of the vitality of spruce stands during the period 2012-2016 (NDRE values) in all three areas. There was a linear decrease in NDRE with increasing values of elevation.

In all three areas, and especially in the area of the Western Sudetes and Eastern Sudetes, an improvement in spruce health in the 800-1000 m. a.s.l range has been observed, whereas in the Western Sudetes, this elevation range is slightly lower (by approximately $100 \mathrm{~m}$ ) than in the Eastern Sudetes. In addition, an improvement in spruce health in the Beskid Ślaski and Żywiecki was observed at an elevation of approximately $1300 \mathrm{~m}$ a.s.l.

The second most important factor affecting the spruce health in all three areas is the age of tree stands. The strongest correlation occurs in the Silesian and Żywiecki Beskids and is slightly lower in the Eastern Sudetes, with the lowest correlation occurring the Western Sudetes. In all three areas, the highest values of the NDRE indicator for the years 2012-2016 occurs in the 40-60 years age group.

In all three areas, the factors with the smallest impact on the value of the NDRE indicator during 2012-2016 were aspect and slope.

Author Contributions: R.B. provided data and carried out the literature review, methodology, text writing and editing. T.H. carried out the literature review, GIS analysis, text writing and editing. A.K. carried out statistical analysis and text writing. K.O.-S. carried out GIS analysis and text editing.

Funding: Data and analysis were collected, and analyses were performedas part of the science project entitled "The creation of the forest informational system for the monitoring and the forest state estimation on the area of Sudety and West Beskidy" financed by the Polish National Forest Holding. The article was funded from a science project entitled: "Influence of biotic, abiotic and anthropogenic factorson the growth dynamics of mountain stands in the Eastern Sudetes on the basis of data from aerial laser scanningand hyperspectral images", supported by Ministry of Science and Higher Education (Grant No. 241502).

Conflicts of Interest: The authors declare no conflict of interest.

\section{Abbreviations}

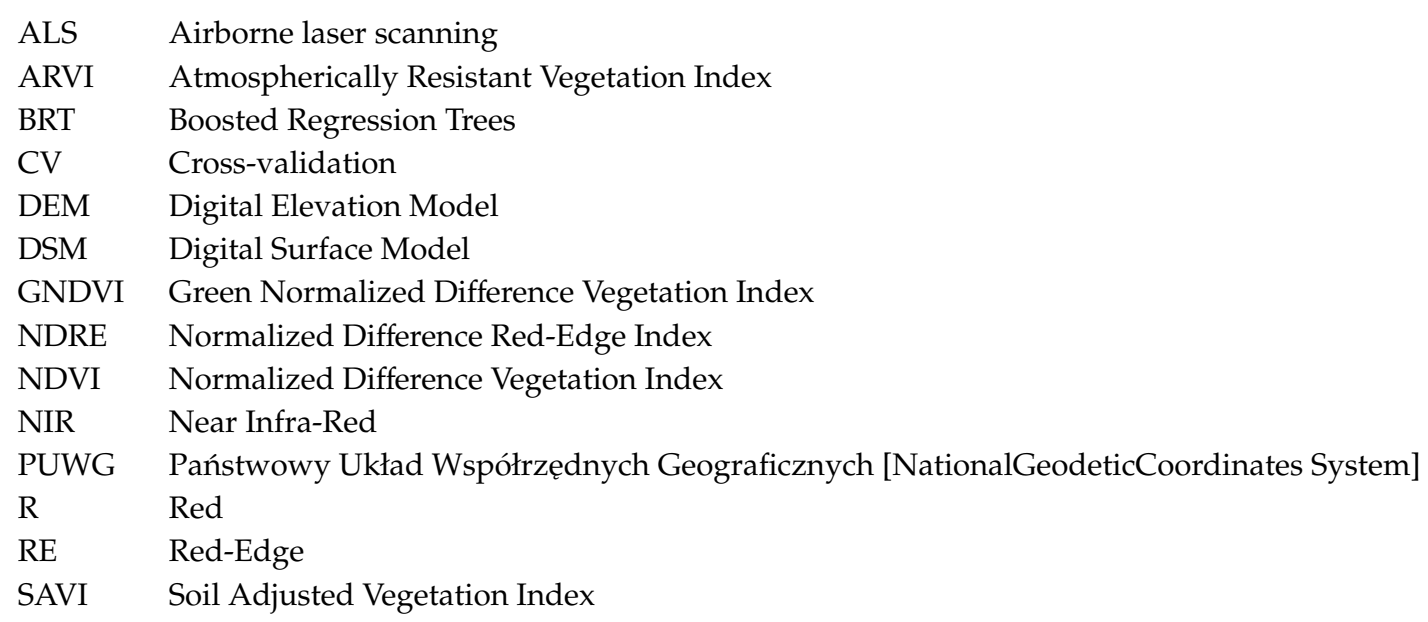

\section{References}

1. Oleksyn, J.; Reich, P.B. Pollution, Habitat Destruction, and Biodiversity in Poland. Conserv. Biol. 1994, 8, 943-960. [CrossRef]

2. Grodzki, W. Zanieczyszczenia przemysłowe a gradacje szkodników owadzich w lasach górskich. Sylwan 1995, 139, 13-19.

3. Modrzyński, J. Defoliation of older Norway spruce (Picea abies /L./ Karst.) stands in the Polish Sudety and Carpathian mountains. For. Ecol. Manag. 2003, 181, 289-299. [CrossRef]

4. Kozak, J. Przestrzenny model degradacji lasów Beskidu Śląskiego. Biul. Kraj. Planu Zarządzania Kryzysowego 1996, 174, 511-538. 
5. Grodzki, W.; McManus, M.; Knížek, M.; Meshkova, V.; Mihalciuc, V.; Novotný, J.; Turčáni, M.; Slobodyan, Y. Occurrence of spruce bark beetles in forest stands at different levels of air pollution stress. Environ. Pollut. 2004, 130, 73-83. [CrossRef] [PubMed]

6. Badea, O.; Tanase, M.; Georgeta, J.; Anisoara, L.; Peiov, A.; Uhlirova, H.; Pajtik, J.; Wawrzoniak, J.; Shparyk, Y. Forest health status in Carpathian Mountains over the period 1997-2001. Environ. Pollut. 2004, 130, 93-98. [CrossRef]

7. Manion, P.D. Tree Disease Concepts; Prentice Hall: Upper Sadle River, NY, USA, 1981.

8. Liwińska, A.; Wawrzoniak, J. Czasowe i przestrzenne zmiany pH i chemizmu opadów atmosferycznych na terenach leśnych o zróżnicowanym poziomie zanieczyszczeń powietrza w Polsce. Pr. IBL 1995, 24, 17-29.

9. Shparyk, Y.; Parpan, V.; Shparyk, Y. Heavy metal pollution and forest health in the Ukrainian Carpathians. Environ.Pollut. 2004, 130, 55-63. [CrossRef]

10. Vacek, S.; Hůnová, I.; Vacek, Z.; Hejcmanovám, P.; Podrázskŷ, V.; Král, J.; Putalová, T.; Moser, K. Effects of air pollution and climatic factors on Norway spruce forests in the Orlicke' hory Mts. (Czech Republic) 1979-2014. Eur.J. For. Res. 2015, 134, 1127-1142. [CrossRef]

11. Schelhaas, M.-J.; Nabuurs, G.-J.; Schuck, A. Natural disturbances in the European forests in the 19th and 20th centuries. Glob. Chang. Biol. 2003, 9, 1620-1633. [CrossRef]

12. Grodzki, W. Spatio-temporal patterns of the Norway spruce decline in the Beskid Ślaski and Żywiecki (Western Carpathians) in southern Poland. J. For. Sci. 2007, 53, 38-44. [CrossRef]

13. Svoboda, M.; Fraver, S.; Janda, P.; Bace, R.; Zenahlikova, J. Natural development and regeneration of a Central European mountain spruce forest. For. Ecol. Manag. 2010, 260, 707-714. [CrossRef]

14. Svoboda, M.; Janda, P.; Nagel, T.; Fraver, S.; Rejzek, J.; Bace, R. Disturbance history of an old-growth sub-alpine Picea abies stand in the Bohemian Forest Czech Republic. J. Veg. Sci. 2012, 23, 86-97. [CrossRef]

15. Zhao, T.; Krokene, P.; Hu, J.; Christiansen, E.; Bjorklund, N.; Långström, B.; Solheim, H.; Borg-Karlson, A.-K. Induced Terpene Accumulation in Norway Spruce Inhibits Bark Beetle Colonization in a Dose-Dependent Manner. PLoS ONE 2011, 6, e26649. [CrossRef]

16. Hais, M. Changes in Land Cover Temperature and Humidity Parameters Resulting from Spruce Forests Decay in the center of the Sumava National Park. Acta Univ. Carol. Geogr. 2003, 2, 97-107.

17. Błaś, M. Rola Mgły w Przychodzie Wody z Atmosfery I Depozycji Zanieczyszczeń w Wybranych Ekosystemach Sudetów. Ph.D. Thesis, Department of Meteorology and Climatology, Institute of Geography University of Wroclaw, Wroclaw, Poland, 2000.

18. Klopcic, M.; Poljanec, A.; Gartner, A.; Boncina, A. Factors Related to Natural Disturbances in Mountain Norway Spruce (Picea abies) Forests in the Julian Alps. Écoscience 2009, 16, 48-57. [CrossRef]

19. Bałazy, R.; Zasada, M.; Ciesielski, M.; Waraksa, P.; Zawiła-Niedźwiecki, T. Forest dieback processes in the Central European Mountains in the context of terrain topography and selected stand attributes. For. Ecol. Manag. 2019, 435, 106-119. [CrossRef]

20. Ciołkosz, A.; Zawiła-Niedźwiecki, T. Ecological Disaster in the Sudety Mountains as seen on Satellite Images. In Satellite Remote Sensing Forest Atlas of Europe; Beckel, L., Ed.; Justus Perthes Gotha Verlag: Gotha, Germany, 1995; pp. 192-193.

21. Dore, A.J.; Choularton, T.W.; Fowler, D.; Stortion-West, R. Field measurement of wet deposition in an extended region of complex topography. Q. J. R. Meteorol. Soc. 2000, 116, 1193-1212.

22. Sobik, M.; Błaś, M. Natural and Human Impact on Pollutant Deposition in Mountain Ecosystems with the Sudetes as an Example. In Proceedings of the EE'08 Proceedings of the 3rd IASME/WSEAS International Conference on Energy \& Environment, Cambridge, UK, 23 February 2008; pp. 355-359.

23. Hyyppä, H.; Yu, X.; Hyyppä, H.; Kaartinen, H.; Kaasalainen, S.; Honkavaara, E.; Rönnholm, P. Factors affecting the quality of DTM generation in forested areas. Int. Arch. Photogramm. Remote Sens. Spat. Inf. Sci. 2005, 36, 85-90.

24. Main-Knorn, M.; Hostert, P.; Kozak, J.; Kuemmerle, T. How pollution legacies and land use histories shape post-communist forest cover trends in the Western Carpathians. For. Ecol. Manag. 2009, 258, 60-70. [CrossRef]

25. Havasova, M.; Bucha, T.; Ferencik, J.; Jakus, R. Applicability of a vegetation indices-based method to map bark beetle outbreaks in the High Tatra Mountains. Ann. For. Res. 2005, 58, 295-310. 
26. Misurec, J.; Kopackova, V.; Lhotáková, Z.; Campbell, P.; Albrechtova, J. Detection of Spatio-Temporal Changes of Norway Spruce Forest Stands in Ore Mountains Using Landsat Time Series and Airborne Hyperspectral Imagery. Remote Sens. 2016, 8, 92. [CrossRef]

27. Lhotakova, Z.; Albrecgtova, J.; Melanovsky, Z.; Rock, B.N.; Polak, T.; Cudlin, P. Does the azimuth orientation of Norway spruce (Picea abides/L./Karst.) branches within sunlit crown part influence the heterogeneity of biochemical structural and spectral characteristics of needles. Environ. Exp. Bot. 2007, 59, 283-292. [CrossRef]

28. Wang, J.; Sammis, T.D.; Gutschick, V.P.; Gebremichael, M.; Dennis, S.O.; Harrison, R.E. Review of Satellite Remote Sensing Use in Forest Health Studies. Open Geogr. J. 2010, 3, 28-42. [CrossRef]

29. Ya'acob, N.; Azize, A.B.M.; Mahmon, N.A.; Yusof, A.L.; Azmi, N.F.; Mustafa, N. Temporal Forest Change Detection and Forest Health Assessment using Remote Sensing IOP Conference Series. Earth Environ. Sci. 2014, 19, 1-7.

30. Filtchev, L. An Assessment of European Spruce Bark Beetle Infestation Using World View 2 Satellite Data. In Best Practices: Application of GIS Technologies for Conservation of Natural and Cultural Heritage Sites. In Proceedings of the 1st European SCGIS Conference with International Participation, Sofia, Bulgaria, 21-23 May 2012; SRTI-BAS and SCGIS-Bulgaria: Sofia, Bulgaria, 2012; pp. 9-16, ISBN 1314-7749.

31. Eitel, J.U.; Vierling, L.A.; Litvak, M.E.; Long, D.S.; Schulthess, U.; Ager, A.A.; Krofcheck, D.J.; Stoscheck, L. Broadband, red-edge information from satellites improves early stress detection in a New Mexico conifer woodland. Remote Sens. Environ. 2011, 115, 3640-3646. [CrossRef]

32. Marx, A.; Kleinschmit, B. Sensitivity analysis of RapidEye spectral bands and derived vegetation indices for insect defoliation detection in pure Scots pine stands. Iforest Biogeosci. For. 2017, 10, 659-668. [CrossRef]

33. Adelabu, S.; Mutanga, O.; Adam, E. Evaluating the impact of red-edge band from Rapideye image for classifying insect defoliation levels. ISPRSJ. Photogramm. Remote Sens. 2014, 95, 34-41. [CrossRef]

34. Xiao, Q.; McPherson, E.G. Tree health mapping with multispectral remote sensing data at UC Davis, California. Urban Ecosyst. 2005, 8, 349-361. [CrossRef]

35. Jaworski, A.; Pach, M. A comparison of lower montane natural forest (Abies, Fagus, Picea) in Oszast Reserve and spruce monocultures in the Żywiecki Beskid and Śląski Beskid. For. Res. Pap. 2014, 75, 13-23. [CrossRef]

36. Forest Data Bank. Available online: https://www.bdl.lasy.gov.pl/portal/lasy-na-swiecie-en (accessed on 10 October 2019).

37. Mezei, P.; Grodzki, W.; Blaženec, M.; Škvarenina, J.; Brandýsová, V.; Jakuš, R. Host and site factors affecting tree mortality caused by the spruce bark beetle (Ips typographus) in mountainous conditions. For. Ecol. Manag. 2014, 331, 196-207. [CrossRef]

38. Elith, J.; Leathwick, J.R.; Hastie, T. A working guide to boosted regression trees. J. Anim. Ecol. 2008, 77, 802-813. [CrossRef] [PubMed]

39. Boosted Regression Trees for Ecological Modelling. Available online: https://cran.r-project.org/web/packages/ dismo/vignettes/brt.pdf (accessed on 8 January 2017).

40. The Gbm Package. Generalized Boosted Regression Models. Available online: http://www.saedsayad.com/ docs/gbm2.pdf (accessed on 23 March 2019).

41. Duigan, S.P.; Richardson, A.D.; Berlyn, G.P. An evaluation of noninvasive methods to estimate foliar chlorophyll content. New Phytol. 2002, 153, 185-194.

42. Zhan, Z.Z.; Liu, H.B.; Li, H.M.; Wu, W.; Zhong, B. The Relationship between NDVI and Terrain Factors-A Case Study of Chongqing. Procedia Environ. Sci. 2012, 12, 765-771. [CrossRef]

43. Dai, S.P.; Zhang, B.; Wang, H.J.; Wang, Y.M.; Guo, L.X.; Wang, X.M.; Li, D. Vegetation cover change and the driving factors over northwest China. J. Arid Land 2011, 3, 25-33.

44. Jin, X.M.; Zhang, Y.K.; Schaepman, M.E.; Clevers, J.G.P.W.; Su, Z. Impact of Elevation and Aspect on the Spatial Distribution of Vegetation in the Qilian Mountain Area with Remote Sensing Data. In Proceedings of the XXI Congress: Silk Road for Information from Imagery: The International Society for Photogrammetry and Remote Sensing, Beijing, China, 3-11 July 2008; Comm. VII, WG VII/7. ISPRS: Beijing, China, 2008; pp. 1385-1390.

45. Sproull, G.J.; Bukowski, M.; McNutt, N.; Zwijacz-Kozica, T.; Szwagrzyk, J. Landscape-Level Spruce Mortality Patterns and Topographic Forecasters of Bark Beetle Outbreaks in Managed and Unmanaged Forests of the Tatra Mountains. Pol. J. Ecol. 2017, 65, 24-37. [CrossRef]

46. Kharuk, V.I.; Im, S.T.; Dvinskaya, M.L.; Golukov, A.S.; Ranson, K.J. Climate-induced mortality of spruce stands in Belarus. Environ. Res. Lett. 2015, 10, 125006. [CrossRef] 
47. Johnson, A.H.; Siccama, T.G.; Silver, W.L.; Battles, J.J. Decline of Red Spruce in High-Elevation Forests of New York and New England. In Acidic Precipitation. Advances in Environmental Science; Adriano, D.C., Havas, M., Eds.; Springer: New York, NY, USA, 1989; Volume 1, pp. 85-112.

48. Faccoli, M.; Bernardinelli, I. Composition and Elevation of Spruce Forests Affect Susceptibility to Bark Beetle Attacks: Implications for Forest Management. Forest 2014, 5, 88-102. [CrossRef]

49. Grodzki, W. Impact of selected stand characteristics on the occurrence of the bark beetle Ips typographus (L.) in the Beskid Żywiecki Mountains. Leśne Pr. Badaw. 2014, 75, 159-169. [CrossRef]

50. Grodzki, W. Influence of Air Pollution on the Menace by Bark Beetles in Spruce Stands of Sudety Mts. in Poland. In Air Pollution and Interactions between Organisms in Forest Ecosystems, Proceedings of the 15th International Meeting of Specialists in Air Pollution Effects on Forest Ecosystems, Tharandt/Dresden, Germany, 9-11 September 1992; Tesche, M., Feiler, S., Eds.; Reidel Publishing: Tharandt/Dresden, Germany, 1992; pp. 271-275.

51. Godek, M.; Błaś, M.; Sobik, M.; Polkowska, Ż.; Cichała-Kamrowska, K.; Namieśnik, J. Environmental Role of Rime Chemistry at Selected Mountain Sites in Poland. Pure Appl. Geophys. 2012, 169, 1093-1106. [CrossRef]

52. Zink, M.; Seifert, F.M. Microwave Remote Sensing for Monitoring Forest Vitality. In Proceedings of the Third ERS Symposium on Space at the Service of our Environment, Florence, Italy, 14-21 March 1997.

53. Modzelewska, A.; Stereńczak, K.; Mierczyk, M.; Maciuk, S.; Bałazy, R.; Zawiła-Niedźwiecki, T. Sensitivity of vegetation indices in relation to parameters of Norway spruce stands. Folia For. Pol. 2017, 59, 85-98. [CrossRef]

54. Sterenczak, K. Comparison of various algorithms for DTM interpolation from LIDAR data in dense mountain forests. Eur. J. Remote Sens. 2016, 49, 599-621. [CrossRef]

55. Sproull, G.J.; Adamus, M.; Szewczyk, J.; Kersten, G.; Szwagrzyk, J. Fine-scale spruce mortality dynamics driven by bark beetle disturbance in Babia Góra National Park, Poland. Eur. J. For. Res. 2016, 135, 507-517. [CrossRef]

56. Bałazy, R.; Kamińska, A.; Ciesielski, M.; Socha, J.; Pierzchalski, M. Modeling the effect of environmental and topographic variables affecting the height increment of Norway spruce stands in mountainous conditions with the use of LiDAR data. Remote Sens. 2019. in print.

57. Opała-Owczarek, M.; Błaś, M.; Owczarek, P.; Sobik, M.; Godek, M. A dendroclimatological study of eastand west-facing slopes in mountainous areas subjected to strong air pollution (the Sudetes, Central Europe). Phys. Geogr. 2018, 40, 186-208. [CrossRef]

58. Decuyper, M.; Chavez, R.O.; Copini, P.; Sass-Klaassen, U. A multi-scale approach to assess the effect of groundwater extraction). J. Arid Environ. 2016, 131, 25-34. [CrossRef] 